\title{
Dose-Response Relationship of Luteinizing Hormone to Luteinizing Hormone-Releasing Hormone in Man
}

\author{
Abba J. Kastin, Andrew V. Schally, Carlos Gual, A. Rees Midgley, Jr., \\ M. Clinton Miller III, and Angela Cabeza \\ From the Endocrine and Polypeptide Laboratories, Endocrinology Section of \\ the Medical Service, Veterans Administration Hospital, and Department of \\ Medicine, Tulane University School of Medicine, New Orleans, Louisiana 70140; \\ Instituto Nacional de la Nutricion, Mexico, D.F.; Department of Pathology, \\ University of Michigan, Ann Arbor, Michigan 48104; and Department of \\ Biometry, Medical University of South Carolina, Charleston, South Carolina 29401
}

A B S T R A C T In previous clinical studies with highly purified porcine luteinizing hormone-releasing hormone ( $\mathrm{LH}-\mathrm{RH}$ ), administration of the somewhat arbitrarily chosen doses of 700-1500 $\mu \mathrm{g}$ resulted in increased serum levels of luteinizing hormone ( $\mathrm{LH}$ ) and follicle-stimulating hormone ( $\mathrm{FSH})$. The present study determined the minimum effective dose as well as the relationship of the response of serum $\mathrm{LH}$ and $\mathrm{FSH}$ to the dose of LH-RH administered. Three normal men received i.v. injections of $1.1-810 \mu \mathrm{g}$ of LH-RH. A dose of $10 \mu \mathrm{g}$ of LH-RH caused a statistically significant elevation in serum LH. $30 \mu \mathrm{g}$ of LH-RH significantly increased serum FSH levels. A highly significant linear trend was observed in the log dose-response curve. The results indicate that both $\mathrm{LH}$ and FSH release occurs in man with doses of LH-RH much lower than previously used and that a linear log dose-response relationship can be obtained.

\section{INTRODUCTION}

Three studies have been reported in which highly purified porcine luteinizing hormone-releasing hormone $(\mathrm{LH}-\mathrm{RH})^{1}$ has been administered to human beings (1-3). The primary purpose of these previous investigations was to demonstrate the effectiveness of this hypothalamic hormone in releasing $\mathrm{LH}$ from the pituitary

Dr. Midgley is a Career Development Awardee of the National Institute of Child Health and Human Development.

Received for publication 8 February 1971 and in revised form 19 April 1971.

${ }^{1}$ Abbreviations used in this paper: $\mathrm{FSH}$, follicle-stimulating hormone; 2nd IRP-HMG, second International Reference Preparation human menopausal gonadotropin; LH$\mathrm{RH}$, luteinizing hormone-releasing hormone. gland of man in a number of clinical and experimental conditions. A single dose of $\mathrm{LH}-\mathrm{RH}$ was used in these tests. This amount, $700-1500 \mu \mathrm{g}$, was calculated on the basis of results obtained from experiments in animals (4-6) and was chosen so as to be reasonably sure of giving an adequate response.

The present study was designed to determine the minimum effective dose of this highly purified preparation of porcine $\mathrm{LH}-\mathrm{RH}$ in releasing $\mathrm{LH}$ in man. At the same time, it was ascertained whether a linear log doseresponse relationship of serum $\mathrm{LH}$ to the administered LH-RH could be demonstrated.

\section{METHODS}

The LH-RH used in this study was the same as that employed in the other clinical studies with porcine LH-RH (1-3). Its preparation from acetic acid extracts of porcine hypothalami was described previously $(6,7)$ and consisted of gel filtration on Sephadex G-25 columns, followed by concentration with phenol, chromatography, and rechromatography on carboxymethylcellulose columns, free-flow electrophoresis, and counter-current distribution. The fraction utilized for this study stimulated $\mathrm{LH}$ release in ovariectomized rats pretreated with estrogen and progesterone at doses of $10 \mathrm{ng}$; it was 10-15 times less potent than our most highly purified preparation of LH-RH (8).

Three normal men, 30-33 yr old, received a single i.v. injection of $\mathrm{LH}-\mathrm{RH}$ at intervals of at least $1 \mathrm{wk}$. The material was dissolved in $0.1 \mathrm{M}$ acetic acid and diluted with saline. The following doses were used: $1.1,3.3,10,30,90$, 270 , and $810 \mu \mathrm{g}$. No side effects whatsoever were noted. Informed, written consent was obtained from all subjects.

Blood was taken from an indwelling i.v. catheter immediately before injection of LH-RH (time 0 ), and 8,16 , 32,64 , and $128 \mathrm{~min}$ later. After centrifugation, the serum was separated and frozen. Serum $\mathrm{LH}$ and follicle-stimulating hormone (FSH) levels were measured by specific radioimmunoassays $(9,10)$ and expressed as milli-International 
Units (mIU) of second International Reference Preparation human menopausal gonadotropin (2nd IRP-HMG) per milliliter serum. $1 \mathrm{mg}$ of LER 907 standard has LH activity equivalent to 210 IU of 2nd IRP-HMG and FSH activity equivalent to $50 \mathrm{IU}$ of 2nd IRP-HMG. LH-RH has no LH or FSH activity in these assays. It has previously been shown that injection of an amount of vasopressin equivalent to that contained in the LH-RH does not significantly affect serum LH and FSH $(1,2)$.

Statistical significance at the 0.05 level was tested by the analysis of variance followed by Duncan's multiple range test among the treatment means for each dose at each time. Linear, quadratic, and cubic effects were obtained for the $\log$ dose and $\log$ time effects.

\section{RESULTS}

The mean response of serum $\mathrm{LH}$ to $\mathrm{LH}-\mathrm{RH}$ at the doses of 1.1 and $3.3 \mu \mathrm{g}$ did not differ significantly from the base line (Table I). Injection of $10 \mu \mathrm{g}$ of LH-RH resulted in a significant increase in serum LH levels beginning $16 \mathrm{~min}$ later. The $8 \mathrm{~min}$ sample at this dose, however, was not significantly elevated. Using $30 \mu \mathrm{g}$ of LH-RH, significant increases in serum $\mathrm{LH}$ were obtained in all samples, although by $128 \mathrm{~min} \mathrm{LH}$ had almost returned to the level obtained before injection. The higher doses of LH-RH $(90,270$, and $810 \mu \mathrm{g})$ significantly elevated serum $\mathrm{LH}$ at all the sampling times.

Since the most potent preparations of LH-RH, which appear to be homogeneous, contain FSH-RH activity, FSH levels were also measured $(8,11)$. No significant increases in serum FSH were obtained with $1.1,3.3$, or $10 \mu \mathrm{g}$ of LH-RH (Table II). At a dose of $30 \mu \mathrm{g}$ of LH-RH, a significant increase in serum FSH levels occurred in all samples except the first one $(8 \mathrm{~min})$. Administration of 90,270 , or $810 \mu \mathrm{g}$ of LH-RH caused a significant increase in serum FSH in all the samples as compared with the values obtained before injection.

TABLE I

Mean Serum LH Levels ( $m I U / m l$ ) after Administration of Porcine LH-RH to Three Normal Men

\begin{tabular}{ccccccc}
\hline & \multicolumn{6}{c}{ Time after injection of LH-RH in minutes } \\
\cline { 2 - 7 } Dose & 0 & 8 & 16 & 32 & 64 & 128 \\
\hline$\mu g$ & & & & & & \\
1.1 & 5.4 & 5.7 & 6.5 & 7.0 & 7.0 & 6.7 \\
3.3 & 6.1 & 7.1 & 6.4 & 6.8 & 5.2 & 5.6 \\
10 & 6.5 & 10.3 & $14.5^{*}$ & $12.9^{*}$ & $10.9^{*}$ & $11.7^{*}$ \\
30 & 5.8 & $14.7^{*}$ & $15.8^{*}$ & $13.3^{*}$ & $10.8^{*}$ & 8.3 \\
90 & 6.0 & $18.8^{*}$ & $22.7^{*}$ & $22.2^{*}$ & $17.4^{*}$ & $12.5^{*}$ \\
270 & 7.4 & $19.5^{*}$ & $24.9^{*}$ & $21.9^{*}$ & $17.5^{*}$ & $12.6^{*}$ \\
810 & 6.8 & $20.1^{*}$ & $27.6^{*}$ & $24.1^{*}$ & $21.6^{*}$ & $19.4^{*}$ \\
\hline
\end{tabular}

* Values indicated by an asterisk are significantly different from those obtained before injection of $\mathrm{LH}-\mathrm{RH}$ (time 0 ) at each time.
TABLE II

Mean Serum FSH Levels ( $m I U / m l)$ after Administration of Porcine LH-RH to Three Normal Men

\begin{tabular}{crrrrrr}
\hline & \multicolumn{6}{c}{ Time after injection of $\mathrm{LH}-\mathrm{RH}$ in minutes } \\
\cline { 2 - 7 } Dose & \multicolumn{1}{c}{0} & 8 & 16 & 32 & 64 & 128 \\
\hline$\mu g$ & & & & & & \\
1.1 & 8.3 & 8.6 & 9.0 & 8.7 & 9.2 & 8.9 \\
3.3 & 8.3 & 8.5 & 8.1 & 8.3 & 7.7 & 8.0 \\
10 & 12.4 & 13.3 & 13.3 & 13.2 & 13.3 & $14.0^{*}$ \\
30 & 11.0 & 12.2 & $12.8^{*}$ & $12.8^{*}$ & $13.0^{*}$ & $12.7^{*}$ \\
90 & 10.8 & $13.5^{*}$ & $14.2^{*}$ & $15.5^{*}$ & $13.2^{*}$ & $15.1^{*}$ \\
270 & 11.6 & $13.8^{*}$ & $16.7^{*}$ & $16.7^{*}$ & $17.4^{*}$ & $16.8^{*}$ \\
810 & 7.8 & $11.2^{*}$ & $13.6^{*}$ & $17.6^{*}$ & $17.1^{*}$ & $15.3^{*}$ \\
\hline
\end{tabular}

* Values indicated by an asterisk are significantly different from those obtained before injection of $\mathrm{LH}-\mathrm{RH}$ (time 0 ) at each time.

A highly significant $(P<0.01)$ linear trend in the $\log$ dose-response curve was observed for both $\mathrm{LH}$ and FSH after administration of LH-RH. This is illustrated for $\mathrm{LH}$ in Fig. 1 at the times of maximum response, which usually occurred at $16 \mathrm{~min}$ (Table I).

In addition to there being statistically significant differences in serum $\mathrm{LH}$ and FSH at various times and at various doses, there was a significant difference in the responses of the individual subjects (subject-dose interaction, subject-time interaction). One of the men, in particular, showed consistently low responses to each dose of LH-RH. The statistical tests used in these analyses were based upon a pooled estimate of the error term. This estimate is the best measurement of individual variability and is obtained by adjustment of the total variation by all known sources of variation.

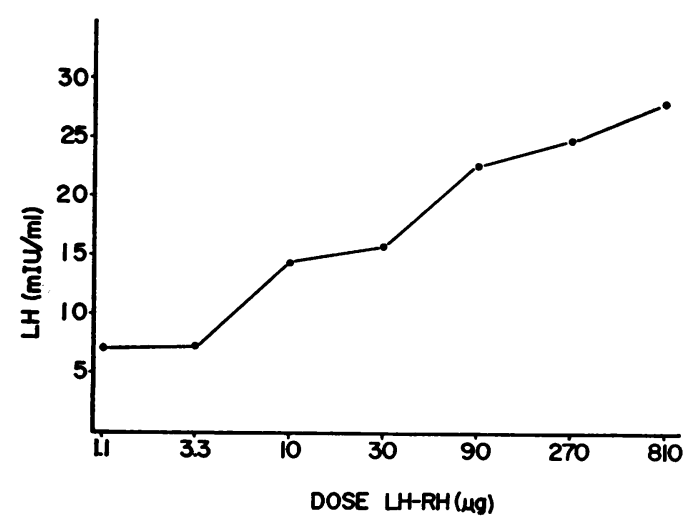

Figure 1 Maximum mean responses of plasma LH levels $(\mathrm{mIU} / \mathrm{ml})$ in three normal men to porcine $\mathrm{LH}-\mathrm{RH}$. The SEM at each point is $1.35 \mathrm{mIU} / \mathrm{ml}$. This was derived from the residual mean square after analysis of variance. 


\section{DISCUSSION}

Previous studies have demonstrated that administration of 700-1500 $\mu \mathrm{g}$ of porcine LH-RH results in elevation of serum $\mathrm{LH}$ values in the human being (1-3). In the present study, the smallest dose of LH-RH which increased serum LH in the three normal men to a level significantly different from that obtained before injection was $10 \mu \mathrm{g}$. This is equivalent to less than $1 \mu \mathrm{g}$ of our most highly purified porcine LH-RH. At this $10 \mu \mathrm{g}$ dose, however, the $8 \mathrm{~min}$ sample did not show a statistically significant elevation. Administration of $30 \mu \mathrm{g}$ of LH-RH resulted in significant increases of serum $\mathrm{LH}$ in all the samples (8-128 $\mathrm{min}$ ).

A slightly higher dose of LH-RH was required to cause significant increases in serum FSH values. Thus, $30 \mu \mathrm{g}$ of LH-RH resulted in elevation of $\mathrm{FSH}$ in each sample except that obtained at $8 \mathrm{~min}$, and $90 \mu \mathrm{g}$ significantly increased FSH levels in all the samples. Biochemical and physiological results suggest that the FSH-RH activity of the most highly purified preparations of porcine $\mathrm{LH}-\mathrm{RH}$ is intrinsic to $\mathrm{LH}-\mathrm{RH}$ rather than due to contamination with FSH-RH $(6,8,11,12)$. The present study again demonstrates that in humans, also, LH-RH releases FSH as well as $\mathrm{LH}(1-3)$. It does not cause consistent changes in the plasma levels of growth hormone, thyrotropin, or cortisol (13).

The linear trend to the log dose-response curve was highly significant $(P<0.01)$. The maximum response of serum $\mathrm{LH}$ to each dose of $\mathrm{LH}-\mathrm{RH}$ has been selected to illustrate this point in Fig. 1. Therefore, in man as in the rat $(6-8), \mathrm{LH}-\mathrm{RH}$ behaves in a manner similar to other hormones, exhibiting a linear log dose-response curve. Significant $\mathrm{LH}$ release can be obtained with doses of LH-RH much smaller than those used previously.

\section{ACKNOWLEDGMENTS}

The authors appreciate the editorial assistance of Dr. E. B. Ferguson, Jr., and the support of Central Office, Veterans Administration, Washington, D. C.

This study was supported by grants from the Research Service, Veterans Administration (Dr. Schally and Dr. Kastin), Population Council (Dr. Midgley), and the Ford Foundation (Dr. Gual).

\section{REFERENCES}

1. Kastin, A. J., A. V. Schally, C. Gual, A. R. Midgley, C. Y. Bowers, and A. Diaz-Infante. 1969. Stimulation of $\mathrm{LH}$ release in men and women by LH-releasing hormone purified from porcine hypothalami. J. Clin. Endocrinol. Metab. 29: 1046.

2. Kastin, A. J., A. V. Schally, C. Gual, A. R. Midgley, C. Y. Bowers, and F. Gomez-Perez. 1970. Administration of LH-releasing hormone to selected subjects. Amer. J. Obstet. Gynecol. 108: 177.

3. Kastin, A. J., A. V. Schally, C. Gual, A. R. Midgley, M. C. Miller, and F. Flores. 1970. Increased release of $\mathrm{LH}$ after administration of LH-RH to men pretreated with clomiphene. J. Clin. Endocrinol. Metab. 31: 689.

4. Arimura, A., and A. V. Schally. 1970. Progesterone suppression of LH-releasing hormone-induced stimulation of LH release in rats. Endocrinology. 87: 643.

5. Arimura, A., and A. V. Schally. 1971. Augmentation of pituitary responsiveness to LH-releasing hormone (LHRH) by estrogen. Proc. Soc. Exp. Biol. Med. 136: 290.

6. Schally, A. V., A. Arimura, A. J. Kastin, J. Reeves, C. Y. Bowers, Y. Baba, and W. F. White. 1970. Hypothalamic LH-releasing hormone: chemistry, physiology, and effect in humans. In Mammalian Reproduction. $\mathrm{H}$. Gibian and E. J. Plotz, editors. Springer-Verlag, Berlin. 45.

7. Schally, A. V., C. Y. Bowers, W. F. White, and A. I. Cohen. 1967. Purification and in vivo and in vitro studies with porcine luteinizing hormone-releasing factor (LRF). Endocrinology. 81: 77.

8. Schally, A. V., A. Arimura, Y. Baba, R. M. G. Nair, H. Matsuo, T. W. Redding, L. Debeljuk, and W. F. White. 1971. Purification and properties of the $\mathrm{LH}$ and FSH-releasing hormone from porcine hypothalami. Abstracts of the 53rd Endocrine Society Meeting. A-70.

9. Midgley, A. R. 1966. Radioimmunoassay: a method for human chorionic gonadotropin and human luteinizing hormone. Endocrinology. 79: 10.

10. Midgley, A. R. 1967. Radioimmunoassay for human follicle-stimulating hormone. J. Clin. Endocrinol. Metab. 27: 295.

11. Schally, A. V., A. Arimura, Y. Baba, R. M. G. Nair, H. Matsuo, T. W. Redding, L. Debeljuk, and W. F. White. Isolation and properties of the FSH and LHreleasing hormone. 1971. Biochem. Biophys. Res. Commun. 43: 393.

12. Schally, A. V., Y. Baba, A. Arimura, T. W. Redding, and W. F. White. 1971. Evidence for peptide nature of $\mathrm{LH}$ and FSH-releasing hormones. Biochem. Biophys. Res. Commun. 42: 50.

13. Kastin, A. J., A. V. Schally, D. S. Schalch, S. G. Korenman, C. Gual, and E. Perez Pasten. 1971. Characterization of the hormonal response to luteinizing hormone releasing hormone (LH-RH). J. Clin. Invest. 50: 53a. (Abstr.) 